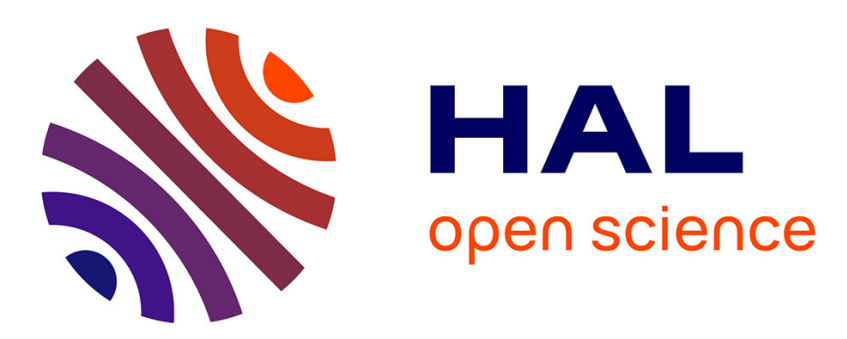

\title{
First evidence of multiple paternity in the bull shark (Carcharhinus leucas)
}

\author{
Agathe Pirog, Sébastien Jaquemet, Marc Soria, Hélène Magalon
}

\section{To cite this version:}

Agathe Pirog, Sébastien Jaquemet, Marc Soria, Hélène Magalon. First evidence of multiple paternity in the bull shark (Carcharhinus leucas). Marine and Freshwater Research, 2015, 10.1071/mf15255 . hal-01253775

\section{HAL Id: hal-01253775 \\ https://hal.science/hal-01253775}

Submitted on 4 May 2016

HAL is a multi-disciplinary open access archive for the deposit and dissemination of scientific research documents, whether they are published or not. The documents may come from teaching and research institutions in France or abroad, or from public or private research centers.
L'archive ouverte pluridisciplinaire HAL, est destinée au dépôt et à la diffusion de documents scientifiques de niveau recherche, publiés ou non, émanant des établissements d'enseignement et de recherche français ou étrangers, des laboratoires publics ou privés. 


\title{
First evidence of multiple paternity in the bull shark (Carcharhinus leucas)
}

\author{
Agathe Pirog $^{\mathrm{A}}$, Sébastien Jaquemet ${ }^{\mathrm{A}, \mathrm{B}}$, Marc Soria $^{\mathrm{C}}$ and Hélène Magalon ${ }^{\mathrm{A}, \mathrm{B}, \mathrm{D}}$ \\ A Université de La Réunion, UMR 9220 ENTROPIE (Université de La Réunion/IRD/CNRS), \\ 15 Avenue René Cassin, CS 92003, F-97744 Saint Denis Cedex 09, La Réunion, France. \\ B Laboratory of Excellence CORAIL, 58, Avenue Paul Alduy, F-66860 Perpignan Cedex, France. \\ CIRD Réunion, UMR 248 MARBEC, CS 410952 rue Joseph Wetzell, F-97492 Sainte-Clotilde, \\ La Réunion, France. \\ ${ }^{\mathrm{D}}$ Corresponding author. Email: helene.magalon@univ-reunion.fr
}

\begin{abstract}
The present study assessed the occurrence of multiple paternity in four litters of bull shark Carcharhinus leucas ( $n=5,8,9$ and 11 embryos) sampled at Reunion Island in the Western Indian Ocean. Using 21 microsatellite loci, we revealed that two litters were generated from two sires each, demonstrating for the first time multiple paternity for this species. We also reported a high paternal skew (10:1 in Litter 1 and $7: 1$ in Litter 3), which may be because of postcopulatory or post-zygotic selection processes. These results contribute to a better understanding of the reproductive behaviour of the bull shark, which remains poorly documented. The present study must be expanded to assess the frequency of multiple paternity in this species, and to test for genetic or cryptic benefits (convenience polyandry), which is important for long-term conservation and management plans.
\end{abstract}

\section{Introduction}

Compared with teleosts, elasmobranchs are usually characterised by low fecundity, low growth rates and late sexual maturity (Myers et al. 1999; Frisk et al. 2001; Dulvy et al. 2008) and are therefore very sensitive to overexploitation (Musick et al. 2000; Ferretti et al. 2010; Dulvy et al. 2014). Their populations are also slow to rebound from depletion (Smith et al. 1998; Myers and Worm 2005). Consequently, knowledge of their reproductive behaviour is important for developing management and conservation plans (Neff and Pitcher 2002; Rowe and Hutchings 2003). A wide variety of reproductive systems in elasmobranchs has been described, ranging from viviparity to oviparity (Compagno 1990, 2001; Conrath et al. 2012), and their mating systems are similarly diverse, with monoandrous and polyandrous species, as well as parthenogenesis being recorded occasionally for captive individuals (Chapman et al. 2007, 2008; Portnoy et al. 2014). Overall, mating systems in sharks remain poorly documented, because they are difficult to study. Although direct observations suggested multiple matings in the nurse shark (Ginglymostoma cirratum) (Pratt and Carrier 2001) and in the whitetip reef shark (Triaenodon obesus) (Whitney et al. 2004), only genetic tools can confirm multiple paternity, identifying full and half-siblings in the same litter. To date, genetic studies have shown multiple paternity in several elasmobranch species, including the small-spotted cat shark (Scyliorhinus canicula) (Griffiths et al. 2012), lemon shark
(Negaprion brevirostris), sandbar shark (Carcharhinus plumbeus), bonnet head shark (Sphyrna tiburo) and brown smooth hound (Mustelus henlei) (for a review, see Byrne and Avise 2012). Although multiple paternity is common in sharks, variability is observed at both inter- and intraspecific scales (Chapman et al. 2004; Feldheim et al. 2004; Daly-Engel et al. 2007; Portnoy et al. 2007; DiBattista et al. 2008b; Chabot and Haggin 2014) and several hypotheses have been proposed to explain this process, such as indirect benefits or convenience polyandry (Zeh and Zeh 2001; Griffiths et al. 2012).

The bull shark (Carcharhinus leucas) is a large shark species (up to $3.4 \mathrm{~m}$ long) that is widespread in tropical and subtropical coastal waters. Its diet is very diverse, including high trophiclevel prey, which suggests that bull sharks are apex predators playing an important role in structuring marine communities (Daly et al. 2013) through top-down processes (Myers et al. 2007; Heithaus et al. 2008). Typical of most elasmobranchs, bull sharks have a long lifespan, around 39 years (Wintner et al. 2002), and delayed sexual maturity, estimated between 14 and 18 years (Branstetter and Stiles 1987). Thus, bull sharks are sensitive to both recreational and commercial fishing pressures to which they are subjected and, as a result, are classified as Near Threatened in the International Union of Conservation for Nature's Red List (Simpfendorfer and Burgess 2009; Worm et al. 2013). This species exhibits placental viviparity, and each embryo is initially dependent on a yolk sac, which elongates and 
attaches to the uterine wall of the mother after a few weeks, forming a yolk sac placenta. For most of gestation, the mother provides nutrients to the embryo via this yolk sac placenta (Jenson 1976; Compagno 1984; Parsons et al. 2008). Litter sizes range from one to 13 embryos (Compagno 1984), with most litters between six and eight (Pattillo et al. 1997). Recently Nevill et al. (2014) reported a litter size of 14 late stage embryos in the Seychelles, which represents the largest litter size recorded to date for C. leucas. No sperm storage in the oviductal gland has been identified in this species yet, but it has been demonstrated in other carcharhinid species (Pratt and Carrier 2001; Parsons et al. 2008; Fitzpatrick et al. 2012). The bull shark is euryhaline and is able to inhabit both marine and freshwater habitats, including lakes, rivers and estuaries (Compagno 1984). The ability of bull sharks to penetrate freshwater seems mostly related to reproduction, when pregnant females migrate to estuarine areas to give birth (Castro 2011). Despite their ability to travel long distances (Kohler and Turner 2001; Simpfendorfer et al. 2005; Daly et al. 2013; Heupel et al. 2015), several studies have highlighted site fidelity in bull shark populations of Florida (Hueter et al. 2005; Karl et al. 2011), Australia (Tillett et al. 2012) and Fiji (Brunnschweiler and Baensch 2011), and even female reproductive philopatry (Karl et al. 2011). Nevertheless, to our knowledge, polyandry has never been demonstrated for the species.

Herein, using 20 microsatellite loci newly developed for this species (Pirog et al. 2015) and one microsatellite locus developed for the tiger shark Galeocerdo cuvier that cross-amplifies in the bull shark (A. Pirog, unpubl. data), we document the occurrence of multiple paternity in four litters of bull sharks from Reunion Island. Possible implications of this polyandry for population dynamics and management of the species are discussed.

\section{Materials and methods}

Samples were collected from four gravid bull shark females, as well as from unborn pups contained in whole uteri. These specimens were caught by local fishermen between June 2013 and June 2015 on the west coast of Reunion Island $\left(21^{\circ} 6^{\prime} \mathrm{S}, 55^{\circ} 36^{\prime} \mathrm{E}\right)$. Samples consisted of a piece of muscle biopsied on the mother and on each pup ( $n=11,5,8$ and 9 pups per brood) and preserved in $95 \%$ ethanol. Total length (TL) was measured for each individual and the sex of each pup was recorded.

Total genomic DNA was extracted from small pieces of tissues using the DNeasy Blood \& Tissue kit (Qiagen, Hilden, Germany). Genotyping was performed using the 20 microsatellite loci recently developed for C. leucas (Pirog et al. 2015). Moreover, we tested microsatellite loci developed for other shark species and that cross-amplified in the bull shark, namely five developed for Carcharhinus limbatus (Cli-007, Cli-106, Cli-107, Cli-108 and Cli-112; Keeney and Heist 2003) and one developed for G. cuvier (Gc01; A. Pirog, unpubl. data). Polymerase chain reactions (PCR) were performed following the conditions published by Keeney and Heist (2003) for the five loci isolated from C. limbatus (Cli) and Pirog et al. (2015) for the others. Amplicons were run on an ABI 3730 XL sequencer (Applied Biosystems, Foster City, CA, USA) and allele size was determined using Genemapper v 4.0 (Applied Biosystems, Foster City, CA, USA).
The five loci isolated from $C$. limbatus were not used in further analyses because of important stuttering bands and potential scoring errors. The other microsatellite loci amplified were polymorphic for a population of bull shark from Reunion Island $(n=41)$. In all, 21 microsatellite loci were used in subsequent analyses.

The probability of detecting multiple paternity in a litter depends on the polymorphism of the microsatellite loci used (allele frequencies), the number of loci, the number of offspring and putative fathers. This probability was calculated using PrDM (Neff and Pitcher 2002) with six different scenarios. These scenarios were defined according to the number of pups observed in the present study $(n=5-11)$ and the number of fathers recorded in other shark species $(n=2-4)$ with and without paternal skew (number of embryos within a litter sired by each male). Multiple paternity was considered when more than two non-maternal alleles were found in the brood for at least two microsatellite loci. Moreover, full and half-siblings in the litter and putative fathers were inferred using Colony ver. 2.0.4.5 software (Jones and Wang 2010) and a maximum likelihood approach. A polygamous mating system was assumed for both sexes to allow the assignment of half-siblings. A long-run with medium likelihood precision and a genotyping error rate of $1 \%$ was performed.

\section{Results}

In the four litters studied, the number of embryos ranged from 5 to 11 and the sex ratio was biased towards female predominance $(\mathrm{M}: \mathrm{F}=5: 6 ; 1: 4 ; 2: 6$ and $3: 6)$. In each litter, all pups were approximately the same size (Table 1), but the mean size of pups from each litter differed significantly (all $P<0.05$, pairwise Wilcoxon test with Bonferroni correction), except between Litters 1 and $4(P=0.17$, pairwise Wilcoxon test with Bonferroni correction). This may be due to the different gestation stages at which each female was caught and may reflect seasonality in the reproduction of the bull shark. Indeed, it is of note that the mother of Litter 2, with the smallest embryos (as well as the smallest number of embryos), was caught in April, the mothers of Litters 1 and 4 were both caught at the beginning of June, and the mother of Litter 3, with the biggest embryos, was caught at the end of August.

The probability of detecting multiple paternity was high (ranging from 0.75 to 1 according to the number of sires) when broods were comprised of more than eight embryos (Table 2). When broods were comprised of five embryos sired by two males, this probability was lower, especially with paternal skews ( 0.55 to 0.72 ; Table 2$)$. Consequently it is possible that for litters with few embryos the microsatellite loci used in the present study may had led to underestimation of the number of sires.

For two litters, more than two paternal alleles were observed for at least two microsatellite loci (Table 3), with three to four paternal alleles recorded. Therefore, at least two fathers were identified for Litters 1 and 3. For Litters 2 and 4, only one sire was identified, because the criterion of more than two paternal alleles was not recovered for any of the loci. Nevertheless, for Litter 2, it is possible that the number of fathers was underestimated because of the low number of embryos and the 
Table 1. Characteristics of the four litters of bull shark (Carcharhinus leucas) studied from Reunion Island

The mean total length (TL) \pm s.e. is given for each litter (mother not included). Data for mothers are shown in bold

\begin{tabular}{|c|c|c|c|}
\hline & Date of capture & Sex & $\mathrm{TL}(\mathrm{cm})$ \\
\hline \multicolumn{4}{|l|}{ Litter 1} \\
\hline CIRUN100 & $06 / 06 / 2013$ & $\mathbf{F}$ & 285 \\
\hline ClRUN101 & $06 / 06 / 2013$ & $\mathrm{~F}$ & 48 \\
\hline ClRUN102 & $06 / 06 / 2013$ & $\mathrm{M}$ & 47 \\
\hline ClRUN103 & $06 / 06 / 2013$ & $\mathrm{M}$ & 48 \\
\hline ClRUN104 & $06 / 06 / 2013$ & $\mathrm{~F}$ & 45 \\
\hline CIRUN105 & 06/06/2013 & $\mathrm{M}$ & 45 \\
\hline ClRUN106 & $06 / 06 / 2013$ & $\mathrm{M}$ & 50 \\
\hline ClRUN107 & $06 / 06 / 2013$ & $\mathrm{~F}$ & 46 \\
\hline ClRUN108 & $06 / 06 / 2013$ & $\mathrm{~F}$ & 46 \\
\hline ClRUN109 & $06 / 06 / 2013$ & $\mathrm{~F}$ & 46 \\
\hline ClRUN110 & $06 / 06 / 2013$ & $\mathrm{M}$ & 48 \\
\hline CIRUN111 & $06 / 06 / 2013$ & $\mathrm{~F}$ & 46 \\
\hline Mean \pm s.e. & & & $46.8 \pm 0.5$ \\
\hline \multicolumn{4}{|l|}{ Litter 2} \\
\hline CIRUN200 & 28/04/2014 & $\mathbf{F}$ & 301 \\
\hline ClRUN201 & $28 / 04 / 2014$ & $\mathrm{M}$ & 35 \\
\hline ClRUN202 & 28/04/2014 & $\mathrm{F}$ & 36 \\
\hline ClRUN203 & $28 / 04 / 2014$ & $\mathrm{~F}$ & 32 \\
\hline ClRUN204 & $28 / 04 / 2014$ & $\mathrm{~F}$ & 32 \\
\hline ClRUN205 & $28 / 04 / 2014$ & $\mathrm{~F}$ & 32 \\
\hline Mean \pm s.e. & & & $33.4 \pm 0.9$ \\
\hline \multicolumn{4}{|l|}{ Litter 3} \\
\hline CIRUN300 & 26/08/2014 & $\mathbf{F}$ & 295 \\
\hline ClRUN301 & $26 / 08 / 2014$ & $\mathrm{M}$ & 66 \\
\hline ClRUN302 & $26 / 08 / 2014$ & $\mathrm{~F}$ & 66 \\
\hline ClRUN303 & $26 / 08 / 2014$ & $\mathrm{~F}$ & 64 \\
\hline ClRUN304 & $26 / 08 / 2014$ & $\mathrm{~F}$ & 67 \\
\hline CIRUN305 & $26 / 08 / 2014$ & $\mathrm{~F}$ & 67 \\
\hline CIRUN306 & $26 / 08 / 2014$ & M & 68 \\
\hline CIRUN307 & $26 / 08 / 2014$ & $\mathrm{~F}$ & 67 \\
\hline ClRUN308 & $26 / 08 / 2014$ & $\mathrm{~F}$ & 68 \\
\hline Mean \pm s.e. & & & $66.6 \pm 0.5$ \\
\hline \multicolumn{4}{|l|}{ Litter 4} \\
\hline CIRUN400 & $02 / 06 / 2015$ & $F$ & 272 \\
\hline ClRUN401 & $02 / 06 / 2015$ & $\mathrm{M}$ & 45 \\
\hline ClRUN402 & $02 / 06 / 2015$ & $\mathrm{~F}$ & 46 \\
\hline ClRUN403 & $02 / 06 / 2015$ & $\mathrm{~F}$ & 46 \\
\hline ClRUN404 & 02/06/2015 & $\mathrm{F}$ & 46 \\
\hline ClRUN405 & $02 / 06 / 2015$ & $\mathrm{M}$ & 44 \\
\hline ClRUN406 & $02 / 06 / 2015$ & $\mathrm{~F}$ & 47 \\
\hline ClRUN407 & $02 / 06 / 2015$ & $\mathrm{~F}$ & 47 \\
\hline ClRUN408 & $02 / 06 / 2015$ & $\mathrm{~F}$ & 47 \\
\hline CIRUN409 & 02/06/2015 & M & 46 \\
\hline Mean \pm s.e. & & & $46.0 \pm 0.3$ \\
\hline
\end{tabular}

characteristics of the microsatellite loci. For Litter 4, one embryo (ClRUN409) did not express the maternal allele for the locus Cl16, because both the mother and embryo were homozygous, expressing alleles 109 and 107 respectively. Because genotyping and extraction of DNA were performed independently several times (twice for extraction and three for genotyping), it seems reasonable to reject the hypothesis of genotyping errors or sample confusion. Moreover, embryos
Table 2. Probability of detecting multiple paternity for the $\mathbf{2 1}$ microsatellite loci used under six scenarios varying in number of sires and paternal skews

\begin{tabular}{lllll}
\hline & \multicolumn{5}{c}{ Number of embryos } \\
& 5 (Litter 2) 8 (Litter 3) 9 (Litter 4) 11 (Litter 1) \\
\hline Paternal skews & & & & \\
$\quad$ Two males $(50: 50)$ & 0.79 & 0.94 & 0.96 & 0.97 \\
$\quad$ Two males $(66.7: 33.3)$ & 0.72 & 0.9 & 0.92 & 0.95 \\
$\quad$ Two males $(80: 20)$ & 0.55 & 0.75 & 0.79 & 0.85 \\
$\quad \begin{array}{l}\text { Three males } \\
\quad(33.3: 33.3: 33.4)\end{array}$ & 0.91 & 0.99 & 0.99 & 1 \\
$\quad$ Three males & & & & \\
$\quad(57: 28.5: 14.5)$ & 0.84 & 0.96 & 0.97 & 0.99 \\
Four males & & & & \\
$\quad(25: 25: 25: 25)$ & 0.95 & 1 & 1 & 1 \\
\hline
\end{tabular}

Table 3. Allelic evidence of multiple paternity for two litters of bull shark (Carcharhinus leucas) at three microsatellite loci (Cl08, Cl13 and Cl16) for which more than two paternal alleles were detected Allele sizes are in base pairs. Paternal alleles shown in bold. Asterisks indicate one of two alleles from the sire

\begin{tabular}{|c|c|c|c|}
\hline & $\mathrm{Cl} 08$ & Cl13 & Cl16 \\
\hline \multicolumn{4}{|l|}{ Litter 1} \\
\hline ClRUN100 & & 112,116 & 107,111 \\
\hline ClRUN101 & & $112, \mathbf{1 1 2}$ & $\mathbf{1 0 3}, 111$ \\
\hline ClRUN102 & & $112^{*}, 116^{*}$ & $107^{*}, 111^{*}$ \\
\hline ClRUN103 & & $112, \mathbf{1 2 2}$ & $107 *, 111^{*}$ \\
\hline ClRUN104 & & $116, \mathbf{1 2 2}$ & $107^{*}, 111^{*}$ \\
\hline ClRUN105 & & $112, \mathbf{1 2 2}$ & $107, \mathbf{1 0 7}$ \\
\hline ClRUN106 & & $112^{*}, 116^{*}$ & $\mathbf{1 0 3}, 111$ \\
\hline ClRUN107 & & $116, \mathbf{1 2 0}$ & $107, \mathbf{1 0 9}$ \\
\hline ClRUN108 & & $112^{*}, 116^{*}$ & $107^{*}, 111^{*}$ \\
\hline ClRUN109 & & $116, \mathbf{1 2 2}$ & $107^{*}, 111^{*}$ \\
\hline ClRUN110 & & $112 *, 116^{*}$ & 103, 107 \\
\hline ClRUN111 & & $112, \mathbf{1 2 2}$ & $\mathbf{1 0 3}, 111$ \\
\hline Paternal alleles & & $112,116 ?, 120,122$ & $103,107,109,111$ \\
\hline \multicolumn{4}{|l|}{ Litter 3} \\
\hline ClRUN300 & 148,148 & 112,112 & \\
\hline ClRUN301 & 148,154 & $112, \mathbf{1 1 6}$ & \\
\hline ClRUN302 & 148,152 & $112, \mathbf{1 2 2}$ & \\
\hline ClRUN303 & 148,154 & $112, \mathbf{1 2 2}$ & \\
\hline ClRUN304 & 148,152 & $112, \mathbf{1 1 6}$ & \\
\hline ClRUN305 & $148, \mathbf{1 5 2}$ & $112, \mathbf{1 1 6}$ & \\
\hline ClRUN306 & $148, \mathbf{1 4 8}$ & 112,112 & \\
\hline ClRUN307 & 148,154 & $112, \mathbf{1 2 2}$ & \\
\hline CIRUN308 & $148, \mathbf{1 5 4}$ & $112, \mathbf{1 2 2}$ & \\
\hline Paternal alleles & $148,152,154$ & $112,116,122$ & \\
\hline
\end{tabular}

were dissected separately from any other individual, avoiding DNA contamination. Consequently, this singularity seems real.

Finally, for each litter, full and half-siblings were inferred. For Litter 4, to perform the analysis, CIRUN409 was considered to have missing data at the C116 locus. In the two litters with multiple paternity, only one pup (CIRUN107 for Litter 1 and CIRUN306 for Litter 3) was a half-sib with all other pups 


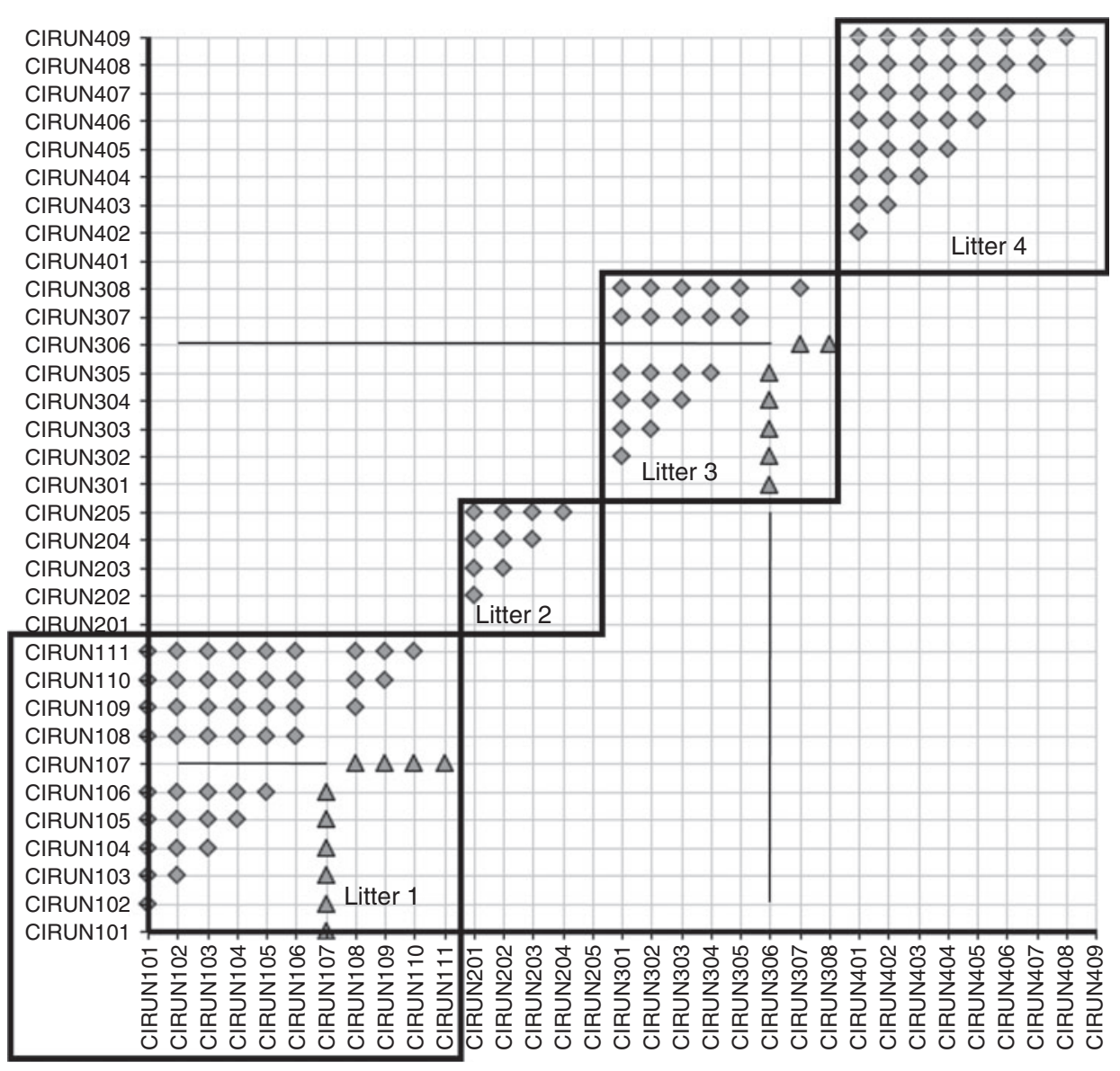

Fig. 1. Sibling relationships (sibships) in the four litters studied. Squares indicate group pups from the same litter. Diamonds (upper diagonal) indicate full siblings; triangles (lower diagonal) indicate half-siblings.

(Fig. 1), confirming that Litters 1 and 3 were fertilised by exactly two males with a high paternal skew $(10: 1$ in Litter 1 and $7: 1$ in Litter 3).

\section{Discussion}

Herein, we provide the first evidence of multiple paternity in C. leucas, with two of four litters being fertilised by two males. Identifying multiple paternity in species is of paramount importance for conservation because it may help maintain genetic diversity in populations (Avise et al. 2002; Frankham et al. 2010) and may increase estimates of effective population size (Sugg and Chesser 1994; Martinez et al. 2000).

Multiple paternity may lead to genetic benefits (for a review, see Thonhauser et al. 2014), including fertility assurance, the good gene hypothesis or the genetic diversity hypothesis (Zeh and Zeh 2001; Thonhauser et al. 2014). An offspring showing higher genetic diversity would express a better fitness and heterozygosity (DiBattista et al. 2008a) and thus these genetic benefits may be detected if multiple paternity is correlated with litter size, heterozygosity or body mass (Zeh and Zeh 2001). Polyandrous litters may be larger than monoandrous litters, as demonstrated for the hammerhead shark ( $S$. tiburo) (Chapman et al. 2004); however, for several shark species, such as the lemon shark ( $N$. brevirostris) (DiBattista et al. 2008a), the brown smooth hound shark (M. henlei) (Byrne and Avise 2012) and the leopard shark Triakis semifasciata (Nosal et al. 2013), no genetic benefits have been demonstrated. In the present study, the sample size was too small to test the correlation between multiple paternity and characteristics of the litters, but it is interesting to note that multiple paternity was not detected in two of four litters, one containing five embryos and the other containing nine embryos. This may suggest that polyandry in the bull shark would not lead to genetic benefits in terms of offspring production, because a smaller litter (eight embryos) was found polyandrous. Nevertheless, a larger sample is required to confirm this observation. Overall, the size of the litters in the present study was in accordance with the average litter size observed in other localities (Compagno 1984; Pattillo et al. 1997).

Post-copulatory mechanisms, such as cryptic female sperm choice, are important and may lead to paternal skews in litters (Jennions and Petrie 2000; Fitzpatrick et al. 2012; Marino et al. 2015). These skews may also be due to post-zygotic processes, as found in the mouse (Mus musculus) (Zeh and Zeh 1997), in which females are able to relocate nutrients between defective and viable embryos. Competition between siblings may also occur, such as intrauterine cannibalism described in the fire 
salamander (Salamandra salamandra) (Dopazo and Alberch 1994) or in the sand tiger shark (Carcharias taurus) (Chapman et al. 2013). In the present study, an important paternal skew was found in the two broods exhibiting multiple paternity $(10: 1$ in Litter 1 and $7: 1$ in Litter 3), which may infer post-copulatory or post-zygotic processes. On the basis of the data of the present study, because the bigger litters were also the most advanced in terms of gestation, it seems unlikely that intrauterine cannibalism occurs, but resource relocation between embryos at a very early stage of gestation may occur. Furthermore, intrauterine cannibalism in sharks has only been reported for C. taurus (Chapman et al. 2013), a species exhibiting size variation within a brood, whereas in the present study the pups within a litter were of a similar size.

Multiple paternity does not always involve genetic benefits and may be the result of convenience polyandry (Wolff and Macdonald 2004; Holman and Kokko 2013), as demonstrated, for example, in the water strider (Gerris buenoi) (Rowe 1992) or in the rock shrimp (Rhynchocinetes typus) (Thiel and Hinojosa 2003). Mating of sharks can be violent for females, which show marks and wounds during the mating season (Brunnschweiler and Baensch 2011) resulting from the males grasping females during copulation (Parsons et al. 2008). In addition, females also exhibit cloacal lesions because of penetration of the male's clasper (Pratt and Carrier 2001). Avoiding mating could imply a cost for the female, which could be higher than accepting the mating. Under these conditions, females will mate with several males, leading to convenience polyandry (DiBattista et al. 2008a; Griffiths et al. 2012). This may be the case for the bull shark, because the data of the present study do not infer genetic benefits. If this species aggregates seasonally at specific places to reproduce, then convenience polyandry could be favoured to minimise harassment because the probability of mating should be higher. In this case, polyandry would not lead to any genetic benefit, but would limit the decrease in female fitness resulting from wounds inflicted by males during mating (Holman and Kokko 2013).

Interestingly, one embryo (CIRUN409) did not express the maternal allele for the locus $\mathrm{Cl16}$, a dinucleotide (TC) microsatellite (Pirog et al. 2015). The mother was homozygous, expressing the allele 109 for this locus, and embryos of the litter were either heterozygous with alleles 107 and 109, or homozygous 109, except for CIRUN409, which was homozygous with the allele 107 (see Table S1, available as Supplementary material to this paper). We can infer from the other embryos of the litter that the father expressed alleles 107 and 109 for this locus. This anomaly may be due to a mutation that occurred in the mother's germ cells (Ellegren 2004; Ortego et al. 2008), the presence of a null allele (Dakin and Avise 2004; Chapuis and Estoup 2007) or to meiotic errors (e.g. loss of a chromosome; Engel 1980).

In conclusion, the present study provides new insights into the reproductive behaviour of C. leucas, which remains poorly documented. The sampling was insufficient to assess the frequency of multiple paternity in the population of bull sharks of Reunion Island and to test the presence of genetic benefits, but the results tend to support the hypothesis of convenience polyandry. It will be important to expand on this study using non-destructive methods in order to better assess the effects of polyandry on the genetic diversity and estimates of the effective population size of bull sharks in Reunion Island. Finally, in the context of both shark-attack management and conservation of ecological processes associated with bull sharks, efforts need to continue to understand the full reproductive cycle of the species locally and investigate whether reproduction leads to behavioural changes that could partially explain attacks that happen during the mating period, which is, to date, poorly documented in the western Indian Ocean.

\section{Acknowledgements}

The authors thank fishermen T. Gazzo and C. Perry, veterinarians B. Reche and J. Robert, D. Guyomard (Comité Régional des Pêches Maritimes et des Elevages Marins de La Réunion) and all those who helped with sample collection. This study was performed under the scientific program CHARC (Connaissances de l'écologie et de l'habitat de deux espèces de requins côtiers à La Réunion).

\section{References}

Avise, J. C., Jones, A. G., Walker, D. E., and DeWoody, J. A. (2002). Genetic mating systems and reproductive natural histories of fishes: lessons for ecology and evolution. Annual Review of Genetics 36, 19-45. doi:10.1146/ANNUREV.GENET.36.030602.090831

Branstetter, S., and Stiles, R. (1987). Age and growth estimates of the bull shark, Carcharhinus leucas, from the northern Gulf of Mexico. Environmental Biology of Fishes 20, 169-181. doi:10.1007/BF00004952

Brunnschweiler, J. M., and Baensch, H. (2011). Seasonal and long-term changes in relative abundance of bull sharks from a tourist shark feeding site in Fiji. PLoS One 6, e16597. doi:10.1371/JOURNAL.PONE. 0016597

Byrne, R. J., and Avise, J. C. (2012). Genetic mating system of the brown smoothhound shark (Mustelus henlei), including a literature review of multiple paternity in other elasmobranch species. Marine Biology $\mathbf{1 5 9}$ 749-756. doi:10.1007/S00227-011-1851-Z

Castro, J. I. (2011). 'The Sharks of North America.' (Oxford University Press: New York.)

Chabot, C., and Haggin, B. (2014). Frequency of multiple paternity varies between two populations of brown smoothhound shark, Mustelus henlei. Marine Biology 161, 797-804. doi:10.1007/S00227-013-2378-2

Chapman, D. D., Prodohl, P. A., Gelsleichter, J., Manire, C. A., and Shivji, M. S. (2004). Predominance of genetic monogamy by females in a hammerhead shark, Sphyrna tiburo: implications for shark conservation. Molecular Ecology 13, 1965-1974. doi:10.1111/J.1365-294X.2004. 02178.X

Chapman, D. D., Shivji, M. S., Louis, E., Sommer, J., Fletcher, H., and Prodohl, P. A. (2007). Virgin birth in a hammerhead shark. Biology Letters 3, 425-427. doi:10.1098/RSBL.2007.0189

Chapman, D. D., Firchau, B., and Shivji, M. S. (2008). Parthenogenesis in a large-bodied requiem shark, the blacktip shark Carcharhinus limbatus. Journal of Fish Biology 73, 1473-1477. doi:10.1111/J.1095-8649.2008. 02018.X

Chapman, D. D., Wintner, S. P., Abercrombie, D. L., Ashe, J., Bernard, A. M., Shivji, M. S., and Feldheim, K. A. (2013). The behavioural and genetic mating system of the sand tiger shark, Carcharias taurus, an intrauterine cannibal. Biology Letters 9, 20130003. doi:10.1098/RSBL. 2013.0003

Chapuis, M.-P., and Estoup, A. (2007). Microsatellite null alleles and estimation of population differentiation. Molecular Biology and Evolution 24, 621-631. doi:10.1093/MOLBEV/MSL191

Compagno, L. J. V. (1984). 'FAO Species Catalogue: Vol 4. Sharks of the World: An Annotated and Illustrated Catalogue of Shark Species Known to Date. Part 2 - Carcharhiniformes.' (FAO: Rome.) 
Compagno, L. J. V. (1990). Alternative life-history styles of cartilaginous fishes in time and space. Environmental Biology of Fishes 28, 33-75. doi:10.1007/BF00751027

Compagno, L. J. V. (2001). 'Sharks of the World. An Annotated and Illustrated Catalogue of Shark Species Known to Date. Volume 2. Bullhead, Mackerel and Carpet Sharks (Heterodontiformes, Lamniformes and Orectolobiformes).' (FAO: Rome.)

Conrath, C. L., Musick, J. A., Carrier, J. C., and Heithaus, M. R. (2012). Reproductive biology of elasmobranchs. In 'Biology of Sharks and Their Relatives', 2nd edn. (Eds J. C. Carrier, J. A. Musick and M. R. Heithaus.) pp. 291-311. (CRC Press, Taylor \& Francis Group: Boca Raton, FL, USA.)

Dakin, E. E., and Avise, J. C. (2004). Microsatellite null alleles in parentage analysis. Heredity 93, 504-509. doi:10.1038/SJ.HDY.6800545

Daly, R., Froneman, P. W., and Smale, M. J. (2013). Comparative feeding ecology of bull sharks (Carcharhinus leucas) in the coastal waters of the Southwest Indian Ocean inferred from stable isotope analysis. PLoS One 8, e78229. doi:10.1371/JOURNAL.PONE.0078229

Daly-Engel, T. S., Grubbs, R. D., Bowen, B. W., and Toonen, R. J. (2007). Frequency of multiple paternity in an unexploited tropical population of sandbar sharks (Carcharhinus plumbeus). Canadian Journal of Fisheries and Aquatic Sciences 64, 198-204. doi:10.1139/F07-005

DiBattista, J. D., Feldheim, K. A., Gruber, S. H., and Hendry, A. P. (2008a). Are indirect genetic benefits associated with polyandry? Testing predictions in a natural population of lemon sharks. Molecular Ecology 17, 783-795. doi:10.1111/J.1365-294X.2007.03623.X

DiBattista, J. D., Feldheim, K. A., Thibert-Plante, X., Gruber, S. H., and Hendry, A. P. (2008b). A genetic assessment of polyandry and breedingsite fidelity in lemon sharks. Molecular Ecology 17, 3337-3351. doi:10.1111/J.1365-294X.2008.03833.X

Dopazo, H., and Alberch, P. (1994). Preliminary results on optional viviparity and intrauterine siblicide in Salamandra salamandra populations from Northern Spain. Mertensiella 4, 125-137.

Dulvy, N. K., Baum, J. K., Clarke, S., Compagno, L. J. V., Cortes, E., Domingo, A., Fordham, S., Fowler, S., Francis, M. P., and Gibson, C. (2008). You can swim but you can't hide: the global status and conservation of oceanic pelagic sharks and rays. Aquatic Conservation: Marine and Freshwater Ecosystems 18, 459-482. doi:10.1002/ AQC.975

Dulvy, N. K., Fowler, S. L., Musick, J. A., Cavanagh, R. D., Kyne, P. M., Harrison, L. R., Carlson, J. K., Davidson, L. N. K., Fordham, S. V., Francis, M. P., Pollock, C. M., Simpfendorfer, C. A., Burgess, G. H., Carpenter, K. E., Compagno, L. J. V., Ebert, D. A., Gibson, C., Heupel, M. R., Livingstone, S. R., Sanciangco, J. C., Stevens, J. D., Valenti, S., and White, W. T. (2014). Extinction risk and conservation of the world's sharks and rays. eLife 3, e00590. doi:10.7554/ELIFE.00590

Ellegren, H. (2004). Microsatellites: simple sequences with complex evolution. Nature Reviews. Genetics 5, 435-445. doi:10.1038/NRG1348

Engel, E. (1980). A new genetic concept: uniparental disomy and its potential effect, isodisomy. American Journal of Medical Genetics 6 , 137-143. doi:10.1002/AJMG.1320060207

Feldheim, K. A., Gruber, S. H., and Ashley, M. V. (2004). Reconstruction of parental microsatellite genotypes reveals female polyandry and philopatry in the lemon shark, Negaprion brevirostris. Evolution 58, 2332-2342. doi:10.1111/J.0014-3820.2004.TB01607.X

Ferretti, F., Worm, B., Britten, G. L., Heithaus, M. R., and Lotze, H. K. (2010). Patterns and ecosystem consequences of shark declines in the ocean. Ecology Letters 13, 1055-1071. doi:10.1111/J.1461-0248.2010. 01489.X

Fitzpatrick, J. L., Kempster, R. M., Daly-Engel, T. S., Collin, S. P., and Evans, J. P. (2012). Assessing the potential for post-copulatory sexual selection in elasmobranchs. Journal of Fish Biology 80, 1141-1158. doi:10.1111/J.1095-8649.2012.03256.X
Frankham, R., Briscoe, D. A., and Ballou, J. D. (2010). 'Introduction to Conservation Genetics', 2nd edn. (Cambridge University Press: New York.)

Frisk, M. G., Miller, T. J., and Fogarty, M. J. (2001). Estimation and analysis of biological parameters in elasmobranch fishes: a comparative life history study. Canadian Journal of Fisheries and Aquatic Sciences 58, 969-981. doi:10.1139/F01-051

Griffiths, A. M., Jacoby, D. M. P., Casane, D., McHugh, M., Croft, D. P., Genner, M. J., and Sims, D. W. (2012). First analysis of multiple paternity in an oviparous shark, the small-spotted catshark (Scyliorhinus canicula L.). The Journal of Heredity 103, 166-173. doi:10.1093/ JHERED/ESR112

Heithaus, M. R., Frid, A., Wirsing, A. J., and Worm, B. (2008). Predicting ecological consequences of marine top predator declines. Trends in Ecology \& Evolution 23, 202-210. doi:10.1016/J.TREE.2008.01.003

Heupel, M. R., Simpfendorfer, C. A., Espinoza, M., Smoothey, A. F., Tobin, A., and Peddemors, V. (2015). Conservation challenges of sharks with continental scale migrations. Frontiers of Materials Science 2. doi:10.3389/FMARS.2015.00012

Holman, L., and Kokko, H. (2013). The consequences of polyandry for population viability, extinction risk and conservation. Philosophical Transactions of the Royal Society of London - B. Biological Sciences 368, 20120053. doi:10.1098/RSTB.2012.0053

Hueter, R. E., Heupel, M. R., Heist, E. J., and Keeney, D. B. (2005). Evidence of philopatry in sharks and implications for the management of shark fisheries. Journal of Northwest Atlantic Fishery Science 35, 239-247. doi:10.2960/J.V35.M493

Jennions, M. D., and Petrie, M. (2000). Why do females mate multiply? A review of the genetic benefits. Biological Reviews of the Cambridge Philosophical Society 75, 21-64. doi:10.1017/S0006323199005423

Jenson, N. H. (1976). Reproduction of the Bull Shark, Carcharhinus leucas, in the Lake Nicaragua-Rio San Juan System. In 'Investigations of the Ichtyofauna of Nicaraguan Lakes'. (Ed T. B. Thorson.) pp. 539-560. (School of Life Sciences University of Nebraska-Lincoln: Lincoln, NB, USA.)

Jones, O. R., and Wang, J. L. (2010). COLONY: a program for parentage and sibship inference from multilocus genotype data. Molecular Ecology Resources 10, 551-555. doi:10.1111/J.1755-0998.2009.02787.X

Karl, S. A., Castro, A. L. F., Lopez, J. A., Charvet, P., and Burgess, G. H. (2011). Phylogeography and conservation of the bull shark (Carcharhinus leucas) inferred from mitochondrial and microsatellite DNA. Conservation Genetics 12, 371-382. doi:10.1007/S10592-010-0145-1

Keeney, D. B., and Heist, E. J. (2003). Characterization of microsatellite loci isolated from the blacktip shark and their utility in requiem and hammerhead sharks. Molecular Ecology Notes 3, 501-504. doi:10.1046/J.1471-8286.2003.00492.X

Kohler, N. E., and Turner, P. A. (2001). Shark tagging: a review of conventional methods and studies. Environmental Biology of Fishes 60, 191-224. doi:10.1023/A:1007679303082

Marino, I. A. M., Riginella, E., Gristina, M., Rasotto, M. B., Zane, L., and Mazzoldi, C. (2015). Multiple paternity and hybridization in two smooth-hound sharks. Scientific Reports 5, 12919. doi:10.1038/ SREP12919

Martinez, J. L., Moran, P., Perez, J., De Gaudemar, B., Beall, E., and GarciaVazquez, E. (2000). Multiple paternity increases effective size of southern Atlantic salmon populations. Molecular Ecology 9, 293-298. doi:10.1046/J.1365-294X.2000.00857.X

Musick, J. A., Burgess, G., Cailliet, G., Camhi, M., and Fordham, S. (2000). Management of sharks and their relatives (Elasmobranchii). Fisheries (Bethesda, Md.) 25, 9-13. doi:10.1577/1548-8446(2000)025<0009: MOSATR $>2.0 . \mathrm{CO} ; 2$

Myers, R. A., and Worm, B. (2005). Extinction, survival or recovery of large predatory fishes. Philosophical Transactions of the Royal Society of 
London - B. Biological Sciences 360, 13-20. doi:10.1098/RSTB. 2004.1573

Myers, R. A., Bowen, K. G., and Barrowman, N. J. (1999). Maximum reproductive rate of fish at low population sizes. Canadian Journal of Fisheries and Aquatic Sciences 56, 2404-2419. doi:10.1139, F99-201

Myers, R. A., Baum, J. K., Shepherd, T. D., Powers, S. P., and Peterson, C. H. (2007). Cascading effects of the loss of apex predatory sharks from a coastal ocean. Science 315, 1846-1850. doi:10.1126/SCIENCE. 1138657

Neff, B. D., and Pitcher, T. E. (2002). Assessing the statistical power of genetic analyses to detect multiple mating in fishes. Journal of Fish Biology 61, 739-750. doi:10.1111/J.1095-8649.2002.TB00908.X

Nevill, J. E. G., Bamboche, D., and Philoe, H. (2014). Record litter size for the bull shark, Carcharhinus leucas (Muller \& Henle, 1839), documented in the Seychelles. Western Indian Ocean Journal of Marine Science $\mathbf{1 2}, 85$.

Nosal, A. P., Lewallen, E. A., and Burton, R. S. (2013). Multiple paternity in leopard shark (Triakis semifasciata) litters sampled from a predominantly female aggregation in La Jolla, California, USA. Journal of Experimental Marine Biology and Ecology 446, 110-114. doi:10.1016/ J.JEMBE.2013.05.002

Ortego, J., Aparicio, J. M., Cordero, P. J., and Calabuig, G. (2008). Characteristics of loci and individuals are associated with germline microsatellite mutation rates in lesser kestrels (Falco naumanni). Mutation Research. Fundamental and Molecular Mechanisms of Mutagenesis 648, 82-86. doi:10.1016/J.MRFMMM.2008.09.012

Parsons, G. R., Hoffmayer, E. R., Frank, J., and Bet-Sayad, W. V. (2008). A review of shark reproductive ecology: life history and evolutionary implications. In 'Fish Reproduction', 1st edn. (Eds M. J. Rocha, A. Aruke and B. G. Kapoor.) pp. 435-469. (CRC Press: Boca Raton, FL, USA.)

Pattillo, M. E., Czapla, T. E., Nelson, D. M., and Monaco, M. E. (1997). 'Distribution and Abundance of Fisheries and Invertebrates in Gulf of Mexico Estuaries, Volume 2: Species Life History Summaries.' ELMR Report 11. (NOAA/NOSS Strategic Environmental Assessments Division: Silver Spring, MD, USA.)

Pirog, A., Blaison, A., Jaquemet, S., Soria, M., and Magalon, H. (2015). Isolation and characterization of 20 microsatellite markers from Carcharhinus leucas (bull shark) and cross-amplification in Galeocerdo cuvier (tiger shark), Carcharhinus obscurus (dusky shark) and Carcharhinus plumbeus (sandbar shark). Conservation Genetics Resources 7, 121-124. doi:10.1007/S12686-014-0308-3

Portnoy, D. S., Piercy, A. N., Musick, J. A., Burgess, G. H., and Graves, J. E. (2007). Genetic polyandry and sexual conflict in the sandbar shark, Carcharhinus plumbeus, in the western North Atlantic and Gulf of Mexico. Molecular Ecology 16, 187-197. doi:10.1111/J.1365-294X. 2006.03138.X

Portnoy, D. S., Hollenbeck, C. M., Johnston, J. S., Casman, H. M., and Gold, J. R. (2014). Parthenogenesis in a whitetip reef shark Triaenodon obesus involves a reduction in ploidy. Journal of Fish Biology 85, 502-508. doi: 10.1111/JFB.12415

Pratt, H. L., and Carrier, J. C. (2001). A review of elasmobranch reproductive behavior with a case study on the nurse shark, Ginglymostoma cirratum. Environmental Biology of Fishes 60, 157-188. doi:10.1023/ A: 1007656126281
Rowe, L. (1992). Convenience polyandry in a water strider: foraging conflicts and female control of copulation frequency and guarding duration. Animal Behaviour 44, 189-202. doi:10.1016/0003-3472(92) 90025-5

Rowe, S., and Hutchings, J. A. (2003). Mating systems and the conservation of commercially exploited marine fish. Trends in Ecology \& Evolution 18, 567-572. doi:10.1016/J.TREE.2003.09.004

Simpfendorfer, C., and Burgess, G. H. (2009). Carcharhinus leucas (Bull Shark). In 'The IUCN Red List of Threatened Species', ver. 2015.1. (International Union for Conservation of Nature and Natural Resources.) Available at http://www.iucnredlist.org/details/39372/0 [Verified 1 May 2015].

Simpfendorfer, C. A., Freitas, G. G., Wiley, T. R., and Heupel, M. R. (2005). Distribution and habitat partitioning of immature bull sharks (Carcharhinus leucas) in a southwest Florida estuary. Estuaries 28, 78-85. doi:10.1007/BF02732755

Smith, S. E., Au, D. W., and Show, C. (1998). Intrinsic rebound potentials of 26 species of Pacific sharks. Marine and Freshwater Research 49 663-678. doi:10.1071/MF97135

Sugg, D. W., and Chesser, R. K. (1994). Effective population sizes with multiple paternity. Genetics 137, 1147-1155.

Thiel, M., and Hinojosa, I. A. (2003). Mating behavior of female rock shrimp Rhynchocinetes typus (Decapoda: Caridea): indication for convenience polyandry and cryptic female choice. Behavioral Ecology and Sociobiology 55, 113-121. doi:10.1007/S00265-003-0677-1

Thonhauser, K. E., Thoß, M., Musolf, K., Klaus, T., and Penn, D. J. (2014). Multiple paternity in wild house mice (Mus musculus musculus): effects on offspring genetic diversity and body mass. Ecology and Evolution 4, 200-209. doi:10.1002/ECE3.920

Tillett, B. J., Meekan, M. G., Field, I. C., Thorburn, D. C., and Ovenden, J. R. (2012). Evidence for reproductive philopatry in the bull shark Carcharhinus leucas. Journal of Fish Biology 80, 2140-2158. doi:10.1111/ J.1095-8649.2012.03228.X

Whitney, N. M., Pratt, H. L., and Carrier, J. C. (2004). Group courtship, mating behaviour and siphon sac function in the whitetip reef shark, Triaenodon obesus. Animal Behaviour 68, 1435-1442. doi:10.1016/ J.ANBEHAV.2004.02.018

Wintner, S. P., Dudley, S. F. J., Kistnasamy, N., and Everett, B. (2002). Age and growth estimates for the Zambezi shark, Carcharhinus leucas, from the east coast of South Africa. Environmental Biology of Fishes 53, 557-566. doi:10.1071/MF01062

Wolff, J. O., and Macdonald, D. W. (2004). Promiscuous females protect their offspring. Trends in Ecology \& Evolution 19, 127-134. doi:10.1016/J.TREE.2003.12.009

Worm, B., Davis, B., Kettemer, L., Ward-Paige, C. A., Chapman, D., Heithaus, M. R., Kessel, S. T., and Gruber, S. H. (2013). Global catches, exploitation rates, and rebuilding options for sharks. Marine Policy $\mathbf{4 0}$, 194-204. doi:10.1016/J.MARPOL.2012.12.034

Zeh, J. A., and Zeh, D. W. (1997). The evolution of polyandry II: postcopulatory defenses against genetic incompatibility. Proceedings of the Royal Society of London - B. Biological Sciences 264, 69-75. doi:10.1098/RSPB.1997.0010

Zeh, J. A., and Zeh, D. W. (2001). Reproductive mode and the genetic benefits of polyandry. Animal Behaviour 61, 1051-1063. doi:10.1006/ ANBE.2000.1705 